garian Monarchy." This was followed by a report on the same topic by the National Committee of Rumanian historians, which was presented by M. Constantinescu. Other papers were L. Katus' "The Social Bases of the Nationality Question in Hungary;" and M. Gross" "The Nationality Question in Croatia during the Era of the Crisis of Dualism." Among those who took part in the discussion were D. Kosary, L. Lolotik, T. M. Islamov, I. Dolmanyos, $\mathrm{H}$. Lemke and $\mathrm{H}$. Mommsen.

On the last day the conference concerned itself with the problem of social democracy. T. Erenyi read a paper entitled "The Hungarian Social Democratic Party and Dualism;" and H. Steiner presented "Contribution to the Theme: "AustroHungarian Social Democracy." 'This subject also evoked considerable comment. Some of those who took part in the debate were M. Gross, E. Ragionieri, R. Neck, J. Droz, P. Reiman, P. Hanák, J. Böhm, R. F. Schmiedt, H. Mommsen and E. März.

The organizers of the conference, D. G. Ránki and Dr. Péter Hanák, stated that all of the papers will be published together in book form. This publication will be a valuable addition to the further study of the problems of the Dual Monarchy particularly in view of the controversial and opposing positions taken by the participants.

In addition to the sessions of the conference, the participants were invited on tours of Budapest and Lake Balaton, to receptions given by the Hungarian Academy of Sciences and the Rumanian Embassy, and to an evening at the opera when three works by Béla Bartók were performed.

Indiana University

Charles Jelavich

\title{
NEWS FROM GERMANY
}

Gerald Stourzh, formerly a docent at the University of Vienna, has been appointed professor of history at the Free University of Berlin. During the summer of 1964 he gave a course on the nationality problems in the Austro-Hungarian monarchy, 1848-1918, at that university. It was the first course dealing with Austrian history which has been given at the Free University of Berlin. 